\title{
Breaking female stereotypes: Bianca Pitzorno's girls and the power of literature on gender socialization
}

\author{
Rompiendo estereotipos femeninos: las protagonistas de Bianca \\ Pitzorno y el poder de la literatura en la socialización de género
}

\author{
Trencant estereotips femenins: les protagonistes de Bianca \\ Pitzorno i el poder de la literatura en la socialització de gènere
}

Dalila Forni. Università di Firenze, Italy. dalila.forni@unifi.it. https://orcid.org/0000-0002-1928-3181

\begin{abstract}
Bianca Pitzorno is one of Italy's most famous children's writers. Her works - more than forty books translated into different languages - often address topics linked to gender identity and femininity. Pitzorno's novels for children usually depict non-canonical female characters: rebel, dynamic and intelligent young girls that fight against adult injustice in order to affirm their agency.

The paper aims to explore female portrayals in Pitzorno's novels and their potential educational impact in reconsidering gender stereotypes and roles from an early age. Literature is one of the most influential tools in the construction of gender ideals and gender socialization. Consequently, positive female models - as Pitzorno's characters - should be offered to young readers from an early age in order to foster an inclusive collective imagination about femininity.

For instance, Extraterrestre alla pari [Aliens on par] (1979) directly focuses on gender issues telling the story of a young alien coming from a planet where young boys and girls do not know their sex until they reach adulthood. For this reason, they are considered as gender-neutral beings. Likewise, L'incredibile storia di Lavinia [Lavinia and the magic ring] (1985) ironically retells Hans Christian Andersen's The Little Match Girl working on humor and female agency. Finally, Principessa Laurentina [Princess Laurentina] (1990) deals with adolescence and family dynamics, offering different portrayals of female identity, from a young age to adulthood.
\end{abstract}

Because of the brilliant and nontraditional depiction of female figures and the deconstruction of gender canon in a simple but captivating way, Pitzorno's novels should be internationally considered in primary school curriculums as a starting point to introduce gender diversity in reading programs and to discuss gender issues with the help of adult figures such as teachers, educators and parents.

Keywords: Bianca Pitzorno, Gender, Children's Literature, Gender Socialization.

\section{Resumen}

Bianca Pitzorno es una de las escritoras de literatura infantil más famosas de Italia. Sus obras - más de cuarenta libros traducidos a diferentes idiomas - abordan temas relacionados con la identidad de 
género y la feminidad. Las novelas infantiles de Pitzorno suelen representar personajes femeninos no convencionales: jóvenes rebeldes, dinámicas e inteligentes que luchan contra la injusticia adulta para afirmar su personalidad.

Este artículo se propone explorar los retratos femeninos en las novelas de Pitzorno y su posible impacto educativo en la reconsideración de los estereotipos y los roles de género desde la infancia. La literatura es una de las principales estrategias para construir los ideales de género e influenciar en la socialización. Por lo tanto, hay que ofrecer modelos femeninos positivos - como los personajes de Pitzorno - a jóvenes lectores y lectoras desde una edad temprana para favorecer una imaginación colectiva inclusiva con respecto a la feminidad.

Por ejemplo, Extraterrestre alla pari [Un extraño entre nosotros] (1979) se ocupa específicamente de las cuestiones de género y cuenta la historia de un joven extraterrestre que proviene de un planeta en el que los niños y las niñas no conocen su sexo hasta que llegan a la edad adulta. Por esta razón, se los considera seres neutrales en cuanto al género. De la misma manera, L'incredibile storia di Lavinia [La increíble historia de Lavinia] (1985) relata irónicamente la obra de Hans Christian Andersen "La pequeña vendedora de fósforos” y trata sobre el humor y la identidad femenina. Por último, Principessa Laurentina [Princesa Laurentina](1990) examina la adolescencia y las dinámicas familiares, ofreciendo diferentes retratos de la identidad femenina.

Por su brillante y nada tradicional representación de las figuras femeninas y por la deconstrucción del canon de género de una manera simple pero cautivadora, las novelas de Pitzorno deberían ser consideradas internacionalmente en los programas de estudios de las escuelas de Primaria como un punto de partida para introducir la diversidad de género en los programas de lectura y para discutir las cuestiones de género con la ayuda de figuras adultas como docentes, educadores y educadoras y familias.

Palabras clave: Bianca Pitzorno, Género, Literatura infantil y juvenil, Socialización de Género

\section{Resum}

Bianca Pitzorno és una de les escriptores de literatura infantil més famoses d'Itàlia. Les seues obres -més de quaranta llibres traduïts a diferents idiomes - aborden temes relacionats amb la identitat de gènere i la feminitat. Les novel-les infantils de Pitzorno solen representar personatge femenins no convencionals: joves rebels, dinàmiques i intel-ligents que lluiten contra la injustícia adulta per tal d'afermar la seua personalitat.

Aquest article es proposa explorar els retrats femenins a les novel-les de Pitzorno i el seu possible impacte educatiu en la reconsideració dels estereotips i els rols de gènere des de la infantesa. La literatura és una de les principals estratègies per construir els ideals de gènere i influir en la socialització. Per tant, cal oferir models femenins positius - com els personatges de Pitzorno - a joves lectors i lectores des d'una edat primerenca per tal d'afavorir una imaginació col·lectiva inclusiva respecte de la feminitat.

Per exemple, Extraterrestre alla pari [Extraterrestres tots plegats] (1979) s'ocupa específicament de les qüestions de gènere i narra la història d'un jove extraterrestre que prové d'un planeta en el qual els infants no coneixen el seu sexe fins que arriben a l'edat adulta. Per aquesta raó es consideren éssers neutrals respecte del gènere. De la mateixa manera, L'incredibile storia di Lavinia [La increïble història de Lavínia] (1985) relata irònicament l'obra de Hans Christian Andersen "La petita venedora de llumins" i tracta sobre l'humor i la identitat femenina. Per últim, Principessa Laurentina [Princesa Laurentina] (1990) examina l'adolescència i les dinàmiques familiars, tot oferint retrats de la identitat femenina.

Per la seua brillant i gens tradicional representació de les figures femenines i per la deconstrucció del cànon de gènere d'una manera simple però captivadora, les novel·les de Pitzorno haurien de ser 
considerades internacionalment en els programes d'estudi de les escoles de Primària com a un punt de partida per tal d'introduir la diversitat de gènere als programes de lectura i per tal de discutir les qüestions de gènere amb l'ajuda de figures adultes com docents, educadors i educadores i famílies.

Paraules clau: Bianca Pitzorno, Gènere, Literatura infantil i juvenil, Socialització de gènere

\section{Literature and gender socialization}

Gender socialization (Stockard, 2006; Bussey \& Bandura, 1999; West C., 1987) is a complex process that influences men and women's lives and their perception of what is culturally considered appropriate for them. Through socialization and indirect education from a very early age, boys and girls, men and women learn what is suitable for their gender in a specific social and cultural context. Gender education is a lifelong process performed in different contexts (family, schools, group of peers, and so on), at different levels (direct and indirect) and through different tools (Ulivieri, 2007; Biemmi, 2012; Brambilla, 2016; Burgio, 2015; Witt, 2001).

Male and female standards can be assimilated through different elements that indirectly build gender identity (Ulivieri, 2007). Popular culture has a particularly strong impact on this learningprocess: products such as toys, magazines, advertisements, literature, cinema, cartoons, videogames, and so on create and reinforce gender norms and stereotypes (Lopez, 2017). Most of these tools - and specifically literature, cinema, and cartoons - use storytelling to indirectly promote specific gender models through the narration of archetypal stories. Indeed, narration is a particularly strong element in endorsing gender ideals. From a very early age, children become familiar with different kinds of stories promoted by different media, such as textbooks, picturebooks, novels, cartoons, films, advertisements, etcetera. Stories are part of children's and teenagers' everyday lives and, for this reason, children's and young adults' narrations can be considered as one of the most effective and influential tools in silently promoting specific roles for boys and girls.

Most of the research on the topic points out that young girls, girls, and women are seldom represented as relevant characters and/or protagonists in works addressed to young audiences, while boys and men are particularly common and are often the main, active characters of the story (Biemmi, 2012). Thus, from a quantitative perspective, girls are underrepresented in 
international children's literature, while from a qualitative point of view, boys and girls are described as opposite extremes with fixed, standard identities that cannot be confused or mixed. For instance, male and female characters are characterized by different adjectives and personalities, different career opportunities, different spaces where they act, different colors that characterize them, etcetera. All these elements work together and create a specific gender ideal that will shape young readers' perceptions of masculinity and femininity in adulthood as well. Even if texts for children are often considered powerless (Faeti, 1995), their impact is silent but constant and works both through words and

If girls lack representation and are often depicted through clichés (they are usually gentle, patient, passive, innocent), boys as well, despite their strong presence in children's

literature, are often misrepresented and linked to a canonic, toxic masculinity that is as dangerous as females' limited representation images at the same time (Trisciuzzi, 2017). Books, cartoons or films representing conventional gender roles promote an archaic and rigid division of gender identity and foster gender-based stereotypes that can be harmful both for girls and for boys (Sunderland, 2011). If girls lack representation and are often depicted through clichés (they are usually gentle, patient, passive, innocent), boys as well, despite their strong presence in children's literature, are often misrepresented and linked to a canonic, toxic masculinity that is as dangerous as females' limited representation (Lopez, 2017; Seveso, 2000).

In order to promote modern, open-minded values and encourage freedom beyond gender cultural norms, non-conventional, stereotype-free books for young readers are necessary both in schools and in families. Through an open-minded collective imagination, gender roles could be revised, and single identities could be understood and accepted even if they do not correspond to a specific canon linked to masculinity and femininity (Beseghi, 1994). Books for children are an influential tool that indirectly offers (or denies) possibilities for young readers (Ulivieri, 2014; Bishop, 1990). For this reason, they should be carefully selected by teachers, educators, and parents, both in schools' curricula and in family-readings.

\section{Bianca Pitzorno: new female identities}

Bianca Pitzorno was born in Sassari (Italy) in 1942, but she currently lives and works in Milan. She graduated in Archeology and worked for Italian television (RAI) dealing with cultural programs for children. Her first book addressed to young readers was published in 1970 (II grande raduno dei cowboy, [The Great Cowboy Gathering]), when she began her career as a writer for children. Her career was extremely multifaceted: she worked as a writer, translator, 
she produced programs for television, wrote plays, screenplays, and songs. Today, she is one of the best-known Italian authors for children and teenagers. Her novels were translated into several languages, such as Spanish, French, German, English, Greek, Polish, and Japanese. In 1996, University of Bologna gave her an honorary degree for her fiction for young readers, while in 2001 she received Italy's Andersen Award for her novel Tornatras (2000), and she was a finalist in Hans Christian Andersen Award (Casella, 2006; Tosi, 2017).

Pitzorno is one of the most appreciated and known Italian authors for children: her books are read in schools by teachers and educators and can be easily found in libraries and bookstores in different editions. Moreover, she is usually known as an

Pitzorno is one of the most appreciated and known Italian authors for children: her books are read in schools by teachers and educators and can be easily found in libraries and bookstores in different editions. Moreover, she is usually known as an author with a particular interest in female identities. Her stories tell about girls' adventure in a realistic and chaotic world which is traditionally populated and explored by male characters. author with a particular interest in female identities. Her stories tell about girls' adventures in a realistic and chaotic world which is traditionally populated and explored by male characters. Pitzorno chooses an exclusive focus on female characters (both girls and teenagers) in order to compensate male dominance in children's literature and to offer young readers a new perspective. Her novels fascinate a great number of kids, who indirectly learn that girls, like boys, can be adventurer, and active protagonists of a story (Catarsi, 2002). Pitzorno was defined as a "literary mother of only female daughters" (Beseghi, 1994, p. 70) since she filled a gap in children's narrations through a complex depiction of female protagonists.

On this issue, Bianca Pitzorno underlines a controversial fact: even if girls statistically read more than boys, they are underrepresented in books for children. Starting from classic children's literature, the author notices that male adventures are usually the only possibility given to girls and boys. Pitzorno realized that female readers needed something more than romance novels or 'chick-lit': they deserved adventures, bildungsroman, stories of grief, joy, growth. In her opinion, literature should present active, strong, clever, adventurous girls as well in order to open children's perception of what is possible for female readers, both in literature and in real life. Nevertheless, Pitzorno often highlighted her passion for children and adults' classics, despite their general neglection of female identity (Caso, 2015). Quoting her words:

\footnotetext{
1 Translated by the author. Original Italian text: "madre letteraria di sole figlie femmine".
} 
For me, classics were a source of incredible pleasure and literary models. If I chaotically try to remember their protagonists, I only see a myriad of men: boys, teenagers, men of different ages, nationalities, with different physical characteristics and different social conditions. Why don't we try to pick some of them? Robinson, Little Lord, Sandokan, [...] Giamburrasca, Mowgli, Remy, David Copperfield [...], Jim and Peter Pan, [...] Gulliver, Christopher Robin, Tom Sawyer... There were books, I remember, that had as main characters a mixed couple of children. However, the girl was a complementary character and was usually sacrificed,[...] she usually was the crybaby that slowed down the adventure because of her fears (Vv. Aa., 1987). ${ }^{2}$

Specifically, the writer was inspired by authors such as Lewis Carroll, Karin Michaëlis, Astrid Lindgren, and Roald Dahl because of their interest in female protagonists that subverted the canons of children's literature. Consequently, Pitzorno often revisited classics from a modern, female perspective. For instance, II barone rampante [The Baron in the Trees] (1957) by Italo Calvino inspired her novel La casa sull'albero [The house in the Tree](1984): Cosimo (Calvino's protagonist) and Aglaia (Pitzorno's main character) both want to live on a tree, but while Cosimo's choice is characterized by constraint, Aglaia decides to live on the trees to reach freedom. In addition, Pinocchio (1881) by Carlo Collodi could be compared to La bambola dell'alchimista [The alchemist's doll](1988): both present a story based on puppets that turn into boys and girls, but while Pinocchio is a book where many deathly overtones are presented, Pitzorno's novel is based on life, energy, freedom. Moreover, The Jungle Book (1893) by Rudyard Kipling and L'amazzone di Alessandro Magno [Alexander the Great's Amazon] (1977) show strong correspondences since both Mowgli and Mirtale grow up in a wolf-family: on the one hand, Mowgli depends on his family; on the other, Mirale's story is based on independence and, again, freedom. (Tosi, 2017, p. 106).

Another singularity in Pitzorno's works is her peculiar approach to children's readers. In Pitzorno's opinion, literature for children should not select a didactic line (Tosi, 2017, p. 108; Pitzorno, 1995). The author states that books for children may have two different narrators:

\footnotetext{
2 Translated by the author. Original text: "Ma torniamo ai classici che furono per me fonte di incomparabili godimenti ed anche modelli letterari. Se richiamo alla mente i loro protagonisti sia pure in modo disorganico e confuso mi vedo circondata da una folla di maschi: bambini, ragazzi, uomini di tutte le età, nazionalità, caratteristiche fisiche, condizioni sociali Vogliamo provare a pescare a caso nel mucchio? Robinson e il Piccolo Principe, Sandokan [...] e Giamburrasca, Mowgli e il Capitano Nemo, Remy e David Copperfield, [...] Jim e Peter Pan, [...] Gulliver, Christopher Robin, Tom Sawyer... C'erano anche libri, ricordo, che avevano per protagonisti una coppia mista di bambini o ragazzi. La bambina però era di solito una comprimaria un po' sacrificata, [...] era addirittura la piagnona che con la sua fragilità e le sue fisime rallentava il ritmo della avventura".
} 
educators and pure narrators. The former tells stories intending to educate children, but they usually appeal to adults more than youngsters because of their strong morals; the latter wants to charm children presenting real-life experiences and real emotions, feelings, anxieties. These narrators usually fascinate kids since they approach the reader as a complex, intelligent person that has an active role in the construction of the story and on its interpretation (Picherle, 2004; Beseghi, 1994). Pitzorno strongly criticizes edu-narrator, while she declares herself a 'pure narrator' that appeals to children with the power of storytelling. Thus, her influence is not direct, overtly didactic and moralistic, but invites children to actively reflect on delicate, contemporary topics that are part of ordinary life.

For this reason, Pitzorno's portrayal of young girls is not simply quantitative. The writer constructs strong, multifaceted young girls that deal with everyday life problems, such as growth, death, divorce, puberty, and so on (Garavini, 2012; Beseghi, 1992). Pitzorno's girls are round characters that For this reason, usually perform predominant roles in the plot (Barsotti, 2006). Furthermore, her girls often act in traditionally male spaces: they do not act at home, in the garden or the school, but explore different settings, they find adventures in open, dangerous places, they walk in the cities, they leave the comfort and security of their homes to meet the outside world. So, Pitzorno's girls reach female empowerment and self-awareness through realistic stories that show the difficulties of growing up. Therefore, the writer's female Pitzorno's portrayal of young girls is not simply quantitative. The writer constructs strong, multifaceted young girls that deal with everyday life problems, such as growth, death, divorce, puberty, and so on Pitzorno's girls are round characters that usually perform predominant roles in the plot characters are not easy to classify: they have a nonstereotypical, complex identity and present different shades of femininity, going beyond gender canons.

Another important characteristic in the portrayal of girls and women in Pitzorno's works is the strength and clarity of their emotions: female and, generally, children's feelings are not denied, but deeply explored and considered a natural part of human identities and behaviors. Pitzorno is not afraid of portraying emotions linked to loss, death, suicide, and separation. All feelings are clearly depicted in her pages to present real human (male and female) experiences and, consequently, real characters (Barsotti, 2006). The author also tells stories about extraordinary events that take place in everyday life, in an ordinary context: her attention to common details that suddenly turn into fantasy make identification easier and encourage her young readers to feel closer to her characters. Little boys and girls who read Bianca Pitzorno's works will easily 
feel part of the common contexts and settings she presents in her novels (Caso, 2015; Tosi, 2017).

Settings are fundamental in Pitzorno's works: sometimes, her stories are set in ancient times, like Middle Ages, or in future times, but they always present issues related to contemporary times. Even when she writes about fantasy or past worlds, she always selects contemporary hints that encourage the reader to reflect on modern topics. Fantasy and reality are interconnected, and they influence each other: starting from real problems, Pitzorno builds imaginary worlds that mix what is ordinary and extraordinary. Moreover, the writer mixes different genres: fairy tales meet the novel and are revised through a contemporary approach, for example in L'incredibile storia di Lavinia [Lavinia and the magic ring], which is both a fairy tale and a novel at the same time.

In Bianca Pitzorno's novels, the reader can perceive how society is evolving considering gender dynamics, social roles, education, labor, and so on (Garavini, 2012). In Pitzorno's works women have new professions (lawyers, engineers, architects) and new roles in family dynamics. This demonstrates women's social empowerment both in literature and in everyday life. Pitzorno deals with femininity, related both to young girls and to older women, offering children a wide spectrum of possible identities. Moreover, Pitzorno chooses particular names - which she selects from books and calendars on the topic - to give the reader peculiar characters that can be easily remembered (Caso, 2015).

Thus, Pitzorno wants children's literature to be free of any kind of censure and wishes to present to young girls and boys every kind of topic, even uneasy issues, if part of their personal experience or if it can catch their interest. So, in her opinion children should be introduced from an early age to the complexity of life through books that cover different shades of identity and a wide range of topics. Traditional education should be surpassed in order to leave young readers free to select what to read (Barsotti, 2006).

The author's personal style is deeply connected to her personal experience regarding literature and education. Pitzorno grew up in a wealthy, well-instructed family, where she had the possibility to read a great variety of books. Women too, in Pitzorno's family, could read and take part in intellectual meetings. Bianca's mother fell in love with Virginia Woolf's works, while her grandmother - despite being a simple housewife who spent her life at home, as a mother and wife of a Greek and Latin professor - loved to read Grazia Deledda. As a consequence, Bianca Pitzorno became a passionate reader as well. 
In addition, little Bianca particularly liked to tell and write stories starting from her personal experience. She explains that writing was her only weapon to retaliate against an adult world that looked at children - and girls in particular - as inferior human beings. In particular, she had a troubled relationship with her teacher, who was a despotic woman that had no respect for her pupils, and specifically for poor girls. Bianca silently looked at her arrogant, violent manners, starting to despise the educational system she was part of: teachers recurred to black pedagogy in order to teach children to be little, perfect adults, without considering their needs, their feelings, their thoughts. Because of her teacher, Bianca started to write against adults and their hypocrisy. Bianca wanted to write about children's lives, showing their perspective in the unbalanced relation they had with adults while trying to encourage disobedience (Caso, 2015). Bianca Pitzorno defines herself as "a little girl who is angry and uses the pen as a weapon to offend and defend herself" (Pitzorno, 1995).

Bianca wrote her stories in the agendas her father received from pharmacies. He gave her those diaries to scribble, but Bianca used them as strong weapons of resistance against her teacher. Her stories became immediately popular amongst her classmates since the evil teacher was usually punished for her behavior. From that moment, Bianca never quit writing and her stories kept on being works of female resistance against an adult, sexist world. Real-life and imagined stories are strongly connected, even if reinterpreted and not purely autobiographical, and for this reason they may have a strong influence on young readers and their perception of their roles in the society. Bianca grew up telling stories and finally became a professional writer that could still hear her young, childish voice. The author declared that, despite being in contact with many children, the only little girl she knows is herself, the girl that she was years ago (Caso, 2015).

Moreover, Pitzorno also wrote many of her books in the 1970s, in a period of resistance and fights, giving an influential contribution which could be contemporary nowadays too. Her books offer complex questions about gender, death, loss, love, giving children the possibility to reflect on compelling topics while reading stories about themselves.

\section{Three case-studies}

The present paper aims to analyze three books by Bianca Pitzorno addressed to different targets, from primary school readers to teenagers: Extraterrestre alla pari [Aliens on par] (1985), L'incredibile storia di Lavinia [Lavinia and the magic ring] (1979) and Principessa Laurentina [Princess Laurentina] (1990). The three novels focus on female identity presenting little girls' experiences through different plots, strategies, and metaphors. These three works demonstrate 
Pitzorno's ability to portray children's identity in different life-phases, from childhood to adolescence, introducing complex topics such as growth, divorce, death, loneliness, revenge, and so on (Beseghi, 1992).

These works can be useful and indirect tools to educate children from different points of view. To begin with, reading these novels, young audiences will be familiar with strong female characters who are usually not so common in the pages

Pitzorno's books help to reconsider gender stereotypes and roles from an early age, fostering an inclusive collective imagination that integrates female protagonists. Therefore, as part of children's literary background, these books have a strong influence on gender socialization and on children's perception of what is suitable for boys and girls, men and women dedicated to children. Both boys and girls will be fascinated by young girls' adventures and will indirectly reconsider female identity and future possibilities for little girls. Pitzorno's books help to reconsider gender stereotypes and roles from an early age, fostering an inclusive collective imagination that integrates female protagonists. Therefore, as part of children's literary background, these books have a strong influence on gender socialization and on children's perception of what is suitable for boys and girls, men and women. Furthermore, these books also present an occasion to introduce gender diversity and discussions about gender norm in scholastic curricula: reading Pitzornos' works, children can discuss - helped by teachers and education -issues related to femininity, masculinity, and childhood. Moreover, thanks to their simple but captivating language and their brilliant, non-canonical plots, these books may create a literary sensibility that cannot be given by other low-quality products. Pitzorno's books also present realistic models, real emotions, feelings, reactions. Consequently, they may involve children directly, helping them empathize with young fictional characters that resemble real children's experiences.

\section{a) Extraterrestre alla pari [Aliens on par]}

Extraterrestre alla pari [Aliens on par] (1979) is a book that openly deals with gender norms and social influences on masculinity and femininity. The novel was inspired by the book Kommt ein Mädchen geflogen [Star girl] by Henry Winterfield, that was published in Italy with the title Piovuta dal cielo in 1973 by the Italian publisher Martin Pescatore (Casella, 2006).

Mo is an alien that lives on planet Deneb. In Deneb, children have no sex until they are sixteen: boys and girls are educated together with no differences based on gender. Mo spends some years on planet Earth, where (s)he is adopted by the Olivieris family, a middle-class couple that 
has no children. The Olivieris immediately want to know Mo's sex to understand how to treat and educate him or her. As remarked by the couple: "If we do not know if he is a boy or a girl, how are we supposed to treat him? Or her?" ${ }^{3}$ (Pitzorno, 2014, p. 12).

Mo cannot say if (s)he is a boy or a girl: his/her real mother never wondered the child's sex since it is an irrelevant matter in Deneb, where children are neutral. So, the Olivieris have Mo tested to solve this mystery, but the alien's weird answers cannot link him or her to a specific sex. So, the Olivieris decide to treat Mo as a boy: he is taught how to drive, he is the boss of a young boyband, he reads books for boys and cannot play with dolls or take care of his little cousins. Finally, the Olivieris manage to discover Mo's sex through blood analysis: he is a girl! Her education immediately changes: Mo cannot drive anymore, she has to wear different clothes and she is often silenced. As pointed out by Zanfabro:

As a boy, Mo is expected to excel in science and mathematics and in all kinds of team play; he leads a group of boys and is never asked where he is or to come home at a certain time. On the contrary, the education of the young Mo as a girl is described in all its normative restrictions. As a girl, Mo loses the freedom she had as a boy: she cannot do anything, and whenever she tries to disagree with something adults tell her, she is silenced. The only thing she can do - and she couldn't as a boy - is wear coloured clothes rather than only blue ones (Zanfabro, 2017).

Mo reflects on this sudden change and cannot explain it:

\begin{abstract}
What's so wrong in being a girl and not a boy? [...] What would change, finally? A word written on a sheet. Mo kept being Mo. From the moment the doctor spoke about it, not a single atom in her body had changed, not a bit of her being (soul, personality, spirit, intelligence, psyche, call it as you want) had changed. (Pitzorno, 2014, p. 82) ${ }^{4}$
\end{abstract}

Although Mo's reflections are correct, her life drastically changes when she is discovered to be a girl. Mo feels lost and embarrassed after this shocking event that completely transforms her life on Earth. Mo is not happy with her new life and feels repressed: she wishes to be herself, beyond gender norms. Therefore, the alien girl decides to leave planet Earth and go back to

\footnotetext{
3 Translated by the author. Original Italian text: "Se non sappiamo se è un maschio o una femmina, qual è il modo in cui lo tratteremo?".

4 Original Italian text: “Cosa c'è, in fondo, di tanto drammatico, nel fatto di essere una ragazzina e non un maschio? [...] Cosa cambiava, indefinitiva? Una parola scritta su un pezzo di carta. Mo era ben sempre Mo. Dal momento in cui il dottor Gil aveva parlato, non un solo atomo del suo corpo, non un briciolo del suo modo di essere fatta dentro (anima, carattere,spirito, intelligenza, psiche, chiamatelocome volete) era cambiato".
} 
Deneb. Some of her human friends decide to flee with Mo in search of a new life: Maria cannot stand female education and feels repressed; similarly, Caterina - Mo's cousin - and Stella want to do the same. Thus, little girls become aware of their condition and decide to rebel and flee to another planet where their identity will be respected and they will have the opportunity to act as they wish, breaking gender standards. Another girl wishes to change her life but chooses a different strategy: Cecilia feels imprisoned as well, but prefers to stay at home and actively rebel the system. She rips her female clothes, she learns how to whistle, she climbs on trees with boys, and so on. Cecilia resists gender norms and performs her own identity without leaving planet Earth.

She will keep resisting with calm and violence, she will keep loving her mother and disobey to her, she will keep beating Luigi and defend him against strangers... There was no reasoning behind her decision: it was a matter of attitude Cecilia felt strong enough, considering her age, to face the entire world (Pitzorno, 2014, p. 111). ${ }^{5}$

This character represents hope for a terrestrial change in women's education, offering an optimistic, happy ending: the last words of the novel are "Good Luck, Cecilia!", so to highlight the girl's importance in transmitting her subversion to other little girls.

Extraterrestre alla pari was published in 1979, a period of feminist riots and discussions, but many critics opposed Pitzorno's approach in dealing with female issues. For instance, Marcello Argilli, a critic, in 1978 decided not to publish the book since he considered it a simplistic and polemic feminism that was already old, outdated. Pitzorno replied that she simply wanted to represent diversity and portray children that does not feel part of our society, that do not feel free to express their personality because of cultural and social norms (Tosi, 2017; Caso, 2015). When the book Extraterrestre alla pari was undoubtedly revolutionary when it came out in the Seventies. Nonetheless, the constitutive limit of such an operation is that, by subverting gender norms, it reconfirms and reinforces the same norms it purports to subvert. Pitzorno's story is imbricated in binarism and the only open possibility seems to be given by the existence of another planet, Deneb, where sexual difference and gender identities are less normative than on Earth was finally published, it was acclaimed and won

5 Original Italian text: "Avrebbe continuato a resistere con calma e con violenza, a voler bene a sua madre e a disubbidirle, a picchiare Luigi e a difenderlo dagli estranei... Non c'era un ragionamento alla base della sua decisione: era una questione di carattere. Cecilia si sentiva abbastanza forte, con i suoi otto anni, da tener testa al mondo intero". 
several awards. However, some critics reflected on the book's limits concerning identity and binarism. For example, Zanfabro stated that:

\begin{abstract}
Extraterrestre alla pari was undoubtedly revolutionary when it came out in the 1970s. Nonetheless, the constitutive limit of such an operation is that, by subverting gender norms, it reconfirms and reinforces the same norms it purports to subvert. Pitzorno's story is imbricated in binarism and the only open possibility seems to be given by the existence of another planet, Deneb, where sexual difference and gender identities are less normative than on Earth (Zanfabro, 2017).
\end{abstract}

Although Zanfabro reflections are well-based, Pitzorno's book was a first, strong attempt to open children's mind about gender issues, offering a new path to follow, new rules to subvert. In this work, Pitozrno encourages a non-sexualized identity, beyond female and male expectations, offering children the possibility to reflect and discuss a contemporary topic such as sexual and cultural differences. Although the main focus of the novel is on female identity, the issues raised by the book may be considered from a male perspective as well - or an agender perspective - trying to understand dangerous stereotypes that construct masculinity.

\title{
b) L'incredibile storia di Lavinia [Lavinia and the magic ring]
}

L'incredibile storia di Lavinia was written in 1981 for a five-year-old friend, Valentina, that wished to hear more stories about poo and pee, a taboo topic that often fascinates children, while disgusts adults. The story of Lavinia was initially transmitted orally, but Valentina liked it so much that Bianca Pitzorno - as she explains in the introduction of the book - decided to print and bind it herself. The work circulated in photocopies for some years and was finally published in a newspaper in 1984 with some notes to help parents in dealing with the taboos of the story. In 1985, the novel was published by EL Edizioni (Caso, 2015; Tosi, 2017).

Lavinia's story was inspired by Hans Christian Andersen well-known fairy tale, The Little Match Girl. As Andersen's little protagonist, Lavinia is a young, homeless girl that sells matches in a cold, snowy Milan. Since she cannot sell any matches, she risks dying in the snow during a stormy night, as the original Little Match girl. However, Pitzorno's novel has an unexpected twist: a yellow cab brings a strange woman, with light blue clothes and a wizard's hat. The woman gives Lavinia a magical ring - in exchange for a match - that has a peculiar power: it can turn everything into poo. Lavinia's life immediately changes with her precious ring: she uses it to survive and to blackmail people to get whatever she wants. For example, the little girl extorts expensive clothes to adults and finds anything she needs, even a flat to live in. Lavinia also decides to help people 
with her magical powers: she sets some animals free from the zoo and she saves a baby. However, Lavinia is so flattered by her new life that turns herself into poo as well while she was looking at her image in a mirror. Clodoveo, a male friend, saves her and helps her find a safer, calmer life: she finds out that friendship is even more powerful than her magic ring (Pitzorno, 2014).

Pitzorno explained that in her opinion it was important to introduce this silenced topic - poo since children's life is usually dictated by a biological

Thus, this humorous and contemporary fairy tale is particularly appreciated by children for two main reasons. Firstly, it clearly speaks about a taboo topic, poop, which is usually eliminated in educative texts since considered not appropriate. Secondly, a powerful, lively female character that breaks social norms and fights against adult power is offered to young rhythm that influences family life as well. When children grow up, this topic turns into something that cannot be spoken (Beseghi, 1991). Consequently, children are attracted by something that is not pronounced by parents and, even more, by teachers and educators. So, the writer fought against social respectability: she wanted to speak about a taboo with irony and make children laugh about it.

Thus, this humorous and contemporary fairy tale is particularly appreciated by children for two main reasons. Firstly, it clearly speaks about a taboo topic, poop, which is usually eliminated in educative texts since considered inappropriate. Secondly, a powerful, lively female character that breaks social norms and fights against adult power is offered to young audiences.

Pitzorno chooses a melancholic story, Andersen's fairy tale, and turns it into an ironical, funny novel. The little match girl is reinterpreted from a different perspective: while in Andersen's tale she is a poor, passive, gentle girl, Lavinia is strong, funny, active, smart, she makes fun of adults and revenges her original character. Pitzorno's protagonist breaks stereotypes linked to femininity and childhood through a weird weapon that ridicules adult figures, highlighting children's necessity to be more powerful and independent. Lavinia wants to revenge herself and all those girls that are forced to act as virtuous, kind, passive children. The novel takes children's side and shows common, unbalanced relationships with adults, breaking gender and cultural norms linked to childhood (Caso, 2015; Tosi, 2017; Casella, 2006). 


\section{c) Principessa Laurentina [Princess Laurentina]}

The novel Principessa Laurentina (1990) deals with topics such as adolescence, divorce, death, loss and is targeted to a different audience: teenagers. The young protagonist of the story, Barbara, moves to Milan with her divorced mother when she decides to marry a man and have a new baby, Laurentina, which is called "principessa" (princess) since her father is a noble engineer. In the beginning, Milan appears to Barbara as a horrible, empty city: the girl feels inadequate, lonely, she has no friends and no interests at all. Barbara slowly starts feeling integrated and makes new friends, but when her mother reads her secret diary, the girl decides to leave Milan to live with her father. Soon after this choice, Barbara's mother dies in an accident in Africa during a trip with her husband, and Barbara feels terribly guilty. Every night, Barbara cannot sleep and for this reason invents a story to convince herself that her mother is still alive. The girl cannot stand the truth and finds relief in storytelling, although she perfectly knows that she will have to deal with her mother's absence and with her regrets (Pitzorno, 2014). In the meantime, her little sister, Laurentina, is given to two old aunts, but Barbara decides to kidnap her and take care of her last connection with her mother. Her mother's death reunites the two sisters and suddenly turns Barbara into a woman. Barbara is now independent and can control her own life, despite being a teenager and despite her suffering. Death tragically helps Barbara in personal growth and maturity.

In this novel, readers cannot find Lavinia's magical elements and irony: Principessa Laurentina presents a real, dramatic, compelling story. Compared to Lavinia, Barbara experiences more complex feelings: she is lonely, fragile, in a different phase of her life. The young protagonist suffers solitude, she can't deal with her new classmates and friends, she misses home and feels alone, melancholic, tired, powerless. She also has to deal with a physical transformation: Barbara is growing up, but she eats a lot of chocolate, gains weight and has many pimples. Consequently, she also feels physically inadequate. In addition, Barbara cannot stand the relationship she has with her mother and with adults in general: she feels totally passive and defenseless, with no power over her life. Quoting the book: "Its awful when adults make decisions for you, and you cannot rebel in any way. You get so angry that you feel suffocated. You feel like a fly in a spider's web" ${ }^{6}$ (Pitzorno, 2014, p. 64).

\footnotetext{
${ }^{6}$ Original Italian text: "È tremendo quando gli adulti decidono per te, e non ti puoi opporre in alcun modo. Ti viene una rabbia impotente che ti soffoca. Ti senti come una mosca nella tela del ragno."
} 
Despite these complex events, the death of her mother is a tragic fact that helps the girl to love another human being and to grow up. Pitzorno softly touches topics such as mourning, adulthood, and responsibilities, giving Barbara a strong personality, which is slowly developed through the story. Although she has to suffer for different reasons, Barbara reaches selfawareness and builds a strong relationship with her sister Laurentina. Family - despite being non-traditional - is portrayed as a source of love and

Despite these complex events, the death of her mother is a tragical fact that helps the girl to love another human being and to grow up. Pitzorno softly touches topics such as mourning, adulthood, and responsibilities, giving Barbara a strong personality, which is slowly developed through the story salvation.

Furthermore, Pitzorno introduces another taboo topic in children's books: death and loss. Besides, the mother's death occurs during a terrible fight between mother and daughter: Barbara's reaction is extremely complex to analyse, but Pitzorno manages to explore the teenager's mind and her inner feeling realistically. Young readers can identify with her because of the truthful reflections and emotions selected by the author. Moreover, Pitzorno argued that this book could help those readers that lost a parent since it delicately addresses the topic of mourning, choosing teenagers' side while portraying their sensibility. Even if the book is not directly educational, it can be interpreted as an indirect, educative tool in dealing with difficult issues such as death. Moreover, the book offers an overview of different kinds of girlhood and womanhood: Pitzorno portrays many female characters in different phases of their lives, from baby Laurentina to young Barbara, besides the girls' mother and the two old aunts (Casella, 2006). Human identity is deeply explored since the writer offers a wide spectrum of models regarding femininity.

\section{Conclusions}

Bianca Pitzorno is a renowned author in Italian children's literature and several of her books have been translated in different languages. In Italy, the writer's stories are often used in schools as a tool for education and entertainment. Pitzorno's books can be approached as a starting point to discuss gender roles and gender norms with children in primary schools. Her books often present female characters that go beyond female canons: active and clever girls that explore the world outside and affirm their identity, their personality, their attitudes.

The present paper focused on three well-known work by Pitzorno - Extraterrestre alla pari [Aliens on par] (1979), L'incredibile storia di Lavinia [Lavinia and the magic ring], and 
(1985) Principessa Laurentina [Princess Laurentina] (1990) - and highlighted their key points regarding gender identity and female awareness. While brilliantly reconstructing the canon of children fiction, Pitzorno offers modern portrayals of little girls and women, depicting different life-phases and relational dynamics. The writer's approach directly involves young readers with funny, grotesque and sarcastic moments, alternated with dramatic and complex passages, where the character's identity is explored in depth.

Consequently, Bianca Pitzorno's books could be considered as precious educational tools to start a discussion about gender standards with little boys and girls, as these works of fiction counteracts gender stereotypes through the fascination of storytelling. Therefore, teachers, parents and educators should carefully consider her works in order to introduce children to the complexity of gender identity from an early age and through a familiar medium, children's literature.

\section{References}

Barsotti, S. (2006). Bianca Pitzorno e le sue bambine. In E. Catarsi, \& F. Bacchetti, "I Tusitala". Scrittori italiani contemporanei di letteratura giovanile (p. 75-96). Pisa: Edizioni del Cerro.

Barsotti, S. (2006). Le storie usate. Calvino, Rodari, Pitzorno: riflessioni pedagogiche e letterarie tra mitologia e fiaba. Milan: Unicopli.

Beseghi, E. (1991). Bianca, Lavinia e le altre. Liber(12), 26-28.

Beseghi, E. (1992). Streghetta, Lavinia, Clorofilla e le altre. In A. Vv., L'insegnante, il testo e l'allieva (p. 40-45). Turin: Rosenberg \& Sellier.

Beseghi, E. (1994). Nel giardino di Gaia. Milano: Mondadori.

Biemmi, I. (2012). Educazione sessista. Turin: Rosenberg\&Seller.

Bishop, R. S. (1990). Mirrors, windows, and sliding glass doors. Perspectives, 6(3), ix-xi.

Brambilla, L. (2016). Divenir donne. L'educazione sociale di genere. Pisa: ETS.

Burgio, G. (2015). Genere ed educazione. Education Sciences \& Society, 6(2), 183-190.

Bussey, K., \& Bandura, A. (1999). Social cognitive theory of gender development and differentiation. Psychological Review, 106(4), 676-713.

Casella, M. (2006). Le voci segrete - Itinerari di iniziazione al femminile nell'opera di Bianca Pitzrono. Milan: Mondadori.

Caso, R. (2015). Scrivere per l'infanzia. Itinerari di formazione al femminile nei romanzi di Bianca Pitzorno. Sintesieonline(11), 9-29.

Catarsi, E. (2002). Gianni Rodari e la letteratura per l'infanzia. Pisa: Del Cerro.

Faeti, A. (1995). I diamanti in cantina. Milan: Bompiani.

Garavini, M. (2012). Bianca Pitzorno: Imagination and Feminism. Bookbird: A Journal of International Children's Literature, 50(4), 90-95.

Lopez, A. G. (Ed.) (2017). Decostruire l'immaginario femminile. Pisa: ETS. 
Picherle, S. B. (2004). Libri, bambini, ragazzi - Incontri tra educazione e letteratura. Milan: Vita e Pensiero.

Pitzorno, B. (1995). Storia delle mie storie. Parma: Nuove Pratiche.

Pitzorno, B. (1997). Un extraño entre nosostros. Madrid: Espasa-Calpe SA.

Pitzorno, B. (2014). Extraterrestre alla pari. Milan: Einaudi Ragazzi.

Pitzorno, B. (2014). L'incredibile storia di Lavinia. Milan: Einaudi Ragazzi.

Pitzorno, B. (2014). Principessa Laurentina. Milan: Mondadori.

Pitzorno, B. (2018). Lavinia and the magic ring. London: Catnip.

Seveso, G. (2000). Fumette. Valentina, Eva Kant, Lara Croft e le altre. Milan: Unicopli.

Stockard, J. (2006). Gender Socialization. In Handbook of the Sociology of Gender. Handbooks of Sociology and Social Research. Boston: Springer.

Sunderland, J. (2011). Language, Gender and Children's Fiction. New York: Continuum.

Tosi, E. (2017). Dalla parte delle bambine. Analisi del contributo di Bianca Pitzorno alla letteratura per l'infanzia. Studia Polensia(6), 108.

Trisciuzzi, M. T. (2017). Image and imagination in education. Visual narrative through children's literature. Ricerche di Pedagogia e Didattica - Journal of Theories and Research in Education, 12(3).

Ulivieri, S. (2007). Educazione al femminile, una storia da scoprire, . Milan: Guerini Scientifica.

Ulivieri, S. (ed.) (2014). Corpi violati. Condizionamenti educativi e violenza di genere. Milan: FrancoAngeli.

Vv. Aa. (1987). Bimbe donne e bambole - Protagoniste bambine nei libri per l'infanzia. Rome: Artemide.

West C., Z. D. (1987). Doing Gender. Gender and Society,, 1(2), 125-151.

Witt, S. D. (2001). The Influence of School and Reading Materials on Children's Gender Role Socialization: An Overview of Literature. Curriculum and Teaching, 15(2).

Zanfabro, G. (2017). Gender Matters: What Is at Stake in Dealing with Children's Literature? Trans-. Revue de littérature générale et comparée, (21).

\section{How to cite this paper:}

Forni, D. (2020). Breaking female stereotypes: Bianca Pitzorno's girls and the power of literature on gender socialization. Journal of Literary Education, (3), pp. 62-79. doi: 10.7203/JLE.3.15998 